\title{
Characterization of polychlorinated biphenyls in surface sediments of the North End Lake, Port Elizabeth, South Africa
}

\author{
E Kampire ${ }^{* 1,2}$, G Rubidge ${ }^{1}$ and JB Adams ${ }^{1}$ \\ ${ }^{\prime}$ Nelson Mandela Metropolitan University, PO Box 77000, Port Elizabeth, 6031, South Africa \\ 2University of Rwanda - College of Education PO Box 5039, Kigali, Rwanda
}

\begin{abstract}
The distribution and concentrations of 6 indicator polychlorinated biphenyl (PCB) congeners, nos. 28, 52, 101, 138, 153 and 180, were determined in surface sediments from the North End Lake in Port Elizabeth, South Africa. Forty-two surficial sediment samples were collected from different locations covering the region that receives the majority of the industrial waste, urban effluents and runoff and thus expected to be contaminated with different degrees of contamination. The analysis was achieved by gas chromatography-mass spectrometry (GC/MS) using the internal standard method. The total PCB concentrations in the samples ranged from 1.60 to $3.06 \mathrm{ng}_{\mathrm{g}} \mathrm{g}^{-1} \mathrm{dry}$ weight $(\mathrm{dw})$. The concentrations of congener profiles showed significant differences. Generally, the highest PCB concentrations were associated with high organic matter contents and small grain size. The highly chlorinated PCBs dominated with regards to the levels in sediments. PCB 138 was the major contributor to the total PCBs and was detected at $100 \%$ of sites. This study provided a snapshot of the PCB contamination status in the North End Lake sediments, and allowed for a comparison between the investigated system and other systems worldwide.
\end{abstract}

Keywords: PCBs, sediments, organic matter, particle size, North End Lake

\section{INTRODUCTION}

PCBs are persistent organic compounds associated with a broad spectrum of negative human health effects due to their bioaccumulation and biomagnification in food chains (Salem et al., 2014; Grimm et al., 2015). PCBs are classified as 209 congeners that are similar in structure but differing in the position and/or number of chlorine atoms (EFSA, 2010).

PCBs were mainly used worldwide between 1930s and 1970s as complex mixtures, such as Aroclor in electrical transformers and capacitors, heat transfer systems, paints, coatings, and flame retardants because of their relatively low flammability and excellent dielectric properties (Erickson and Kaley, 2011). Despite their ban in the late 1970s, PCBs continue to be recorded as one of the major contaminants worldwide due to their properties and release from atmospheric deposition, surface runoff from industrial wastewater discharge, and from municipal waste sites in the environment (Lana et al., 2008). Aquatic sediments contaminated by PCBs may pose potential risks to fish, and in turn to humans and wildlife that consume fish (Sorell and McEvoy, 2013). Fish from the North End Lake may constitute a potential source of PCB exposure in humans.

PCBs are among the organochlorine compounds that typically reside in soils and sediments (Ge et al., 2013). When PCBs are discharged into the aquatic environment, either they are adsorbed onto suspended particulate matter in the water column or deposited onto the surface sediment (Mechlińska et al., 2010). Sediment-bound contaminants are transported in an ecosystem by means of trophic transfer, such as consumption of benthic organisms by fish (Clark et al., 1990). These pollutants tend to bind to sediments for a long period of time, hence

To whom all correspondence should be addressed.

iㅛ +27+250788451398; e-mail: edkampire@gmail.com Received 21 April 2017; accepted in revised form 10 October 2017 sediments act as a natural sink for a variety of organic as well as inorganic contaminants (Alkhatib and Weigand, 2002). High levels of PCBs have been detected in sediment samples from various parts of the world (Kocan et al., 2001; Tashiro et al., 2004). DiPinto et al. (1993) showed that $97 \%$ of PCBs released into the water column are retained by sediments. Accumulation of sediment-sorbed PCBs by benthic organisms is derived from sediment ingestion and/or diffusion from pore water (Zhou and Wong, 2000). The analysis of sediment samples constitutes an important step to assess the environment and impact of anthropogenic activities on aquatic systems. In developing countries, the sources of PCBs have been attributed to the use of transformers and capacitors containing PCB oils (Bentum et al., 2012). These oils enter the environment through poor handling of damaged electrical equipment, leakages, spillage during retro filling, and illegal dumping of PCB-containing waste into the aquatic environment.

In South Africa, Grobler (1994) suggested that PCBs are mainly attributed to the industrial waste and possible dumping of products containing or contaminated by PCBs. Except for the health care waste incinerators, no other facilities exist in South Africa to destroy hazardous PCBs. $\mathrm{PCB}$ processing and distribution has been prohibited in most developed countries since the late 1980s (EFSA, 2010). However, large quantities are still in use or are awaiting destruction, while an unknown amount is still present in the environment (Kanzari et al., 2012). Therefore, the contamination of the environment due to residential and industrial activities is a problem recognized in many African countries (Mansour, 2009). The North End Lake is located in the city of Port Elizabeth where numerous industries are situated. Because of the high level of industrialisation in the surrounding areas, the relatively low-lying North End Lake is subject to contamination due to runoff and possibly some waste from the industries and nearby residential areas. Due to the persistence of PCBs and the resulting harmful effects to organisms and human health, the objective of this study 
was to characterize PCBs in the sediments, and to determine the extent of PCB contamination within the lake in order to evaluate the environmental quality of this aquatic system. Furthermore, this study provides preliminary baseline quantitative information on $\mathrm{PCB}$ contamination in surface sediments for better management of the environment. The resulting data will be useful as a reference on PCB levels for subsequent comparative research.

\section{MATERIALS AND METHODS}

\section{Sampling and sample preparation}

Two sampling trips were undertaken in August 2013 and March 2014 to collect surface sediments in the North End Lake. Thirteen sampling sites were located along the lake (Fig. 1). Sites 1, 10 and 13 were located near the Nelson Mandela Bay Stadium, Sites 2 and 3 were located close to stormwater drains into the lake; Sites 4 and 6 were adjacent to municipal and industrial site drainage pipes into the lake. Sites 5, 7 and 9 were located mid-lake; Site 8 was close to the powerboat club while Sites 11 and 12 were close to residential areas. An electronic global positioning system (GPS 72 H Garmin) (Commercial Marine) was employed to identify the precise location of each site. Some of the sites were selected because of their proximity to industrial areas and inflow drains. A total of 42 surface sediment $(0-20 \mathrm{~cm}$ depth) samples were collected using a stainless steel Van Veen grab sampler. Three independent subsamples per station were collected, except at Site 2 where 3 additional samples were taken due to the close proximity of that site to stormwater runoff. After collection, the sediment samples were thoroughly homogenized using a clean stainless-steel spoon and transferred into polyethylene bags. Samples were then transported to the laboratory where they were stored at $4^{\circ} \mathrm{C}$ prior to further processing. All the samples were air-dried and any foreign objects such as gravel, stones, leaves, plastic fragments and shells were removed and discarded to avoid cross contamination and interference. Subsequently, the dried sediments were ground using a mortar and pestle in order to increase the surface area for extraction. These were then sieved using a stainless-steel sieve (Madison Test Sieve, SABS) $(<1 \mathrm{~mm})$ for homogenization resulting in a fine powder. The powder was transferred into a glass jar sealed with a Teflonlined lid and stored in a freezer at $-20^{\circ} \mathrm{C}$ prior to extraction. Sub-samples of 10 and $40 \mathrm{~g}$ were used for the analysis of total organic matter content and grain size, respectively.

\section{Organic matter content}

The organic matter content in sediments is attributed to the decomposition of organisms and plants by bacteria. The organic matter provides an understanding of sediment cohesion. The organic matter in sediment samples was determined based on the method of Briggs (1977). An estimate of the organic content of the sediments was derived from the mass loss on ignition (LOI) in a muffle furnace. Briefly, the beakers (Pyrex Berzelius) $(50 \mathrm{~mL})$ containing $10 \mathrm{~g}$ of dried sediment at room temperature were placed in a muffle furnace (ashing oven) for $8 \mathrm{~h}$ at $550^{\circ} \mathrm{C}$. The beakers were removed from the ashing oven and placed in desiccators to cool down and the final mass recorded. The percentage of the organic matter was calculated as a loss of mass during ashing from the initial mass.

\section{Analytical procedures}

\section{Sediment sample extraction}

The target compounds were extracted from the sediment samples with an organic solvent. Extraction of PCBs in sediment samples was performed according to the methods of Nie et al. (2005) and Eqani et al. (2012), with slight modifications. Briefly, PCBs were extracted from sediment samples using the Soxhlet extraction method. Masses of $20 \mathrm{~g}$ of air-dried sediments were thoroughly mixed with $20 \mathrm{~g}$ of anhydrous $\mathrm{Na}_{2} \mathrm{SO}_{4}$ to form a free-flowing powder and $5 \mathrm{~g}$ of activated copper powder was added for removal of elemental sulphur. A solution of 2, 4, 5, 6-tetrachloro- $m$-xylene (TCmX) was added to each sample and blank aliquot as a surrogate standard prior to the extraction. Soxhlet extraction was performed on sediment samples using $250 \mathrm{~mL}$ of methylene chloride and hexane (1:1, v/v for $24 \mathrm{~h})$. The extracts were concentrated and evaporated under vacuum with a rotary evaporator to $1 \mathrm{~mL}$ and subjected to clean-up procedure. The levels of contaminant in sediment were reported per unit of dry weight. An aliquot of $2 \mathrm{~g}$ of homogenized wet sediment was dried at $105^{\circ} \mathrm{C}$ in an oven to a constant weight for $24 \mathrm{~h}$ followed by cooling in a desiccator for $30 \mathrm{~min}$ prior to weighing. The weight of the dried aliquot was the dry weight of the sample.

\section{Clean-up}

Most PCBs are stable under acidic conditions; therefore treatment with sulphuric acid was used for the removal of potential chromatographic interferences. The method was adapted from Bi et al. (2002) with slight modifications. Briefly, the concentrated extract $(1 \mathrm{~mL})$ was dissolved in $2 \mathrm{~mL}$ of $\mathrm{n}$-hexane and transferred into a separatory funnel. $2 \mathrm{~mL}$ of sulphuric acid (98\%) was added slowly to the extract and shaken vigorously for $2 \mathrm{~min}$. The inorganic layer was decanted off. Several portions of sulphuric acid were used until the acid layer remained colourless. The organic extracts were passed through anhydrous sodium sulphate and concentrated to $1 \mathrm{~mL}$. However, an acid clean-up alone does not usually remove all of the interfering substances that are present in the samples. An additional clean-up involving the use of adsorption column chromatography was also performed to separate target analytes from other interfering compounds using Florisil (60-100 mesh). A glass column was packed with $10 \mathrm{~g}$ of activated Florisil $\left(130^{\circ} \mathrm{C}\right.$ for $\left.12 \mathrm{~h}\right)$ and $2 \mathrm{~g}$ of anhydrous $\mathrm{Na}_{2} \mathrm{SO}_{4}$ was added on the top for removal of any trace of water. The column was pre-eluted with $40 \mathrm{~mL}$ of hexane. The extract $(1 \mathrm{~mL})$ was loaded into the column and the elution of analytes was carried out using $80 \mathrm{~mL}$ of hexane. The eluates were concentrated by rotary evaporator and under a gentle stream of pure nitrogen. The residue fraction was dissolved into $1 \mathrm{~mL}$ of hexane. Internal standard (PCB 209) was added to each sample prior to GC-MS analysis.

\section{Instrumental analysis}

Analysis of PCBs is ideally performed by gas chromatography (GC) coupled to high- or low-resolution mass spectrometry (MS), and electron impact ionisation (EI) is commonly used for the determination of congener-specific PCBs (Castells et al., 2008). In this study, the extracts were analysed using an Agilent 7890 gas chromatography system 


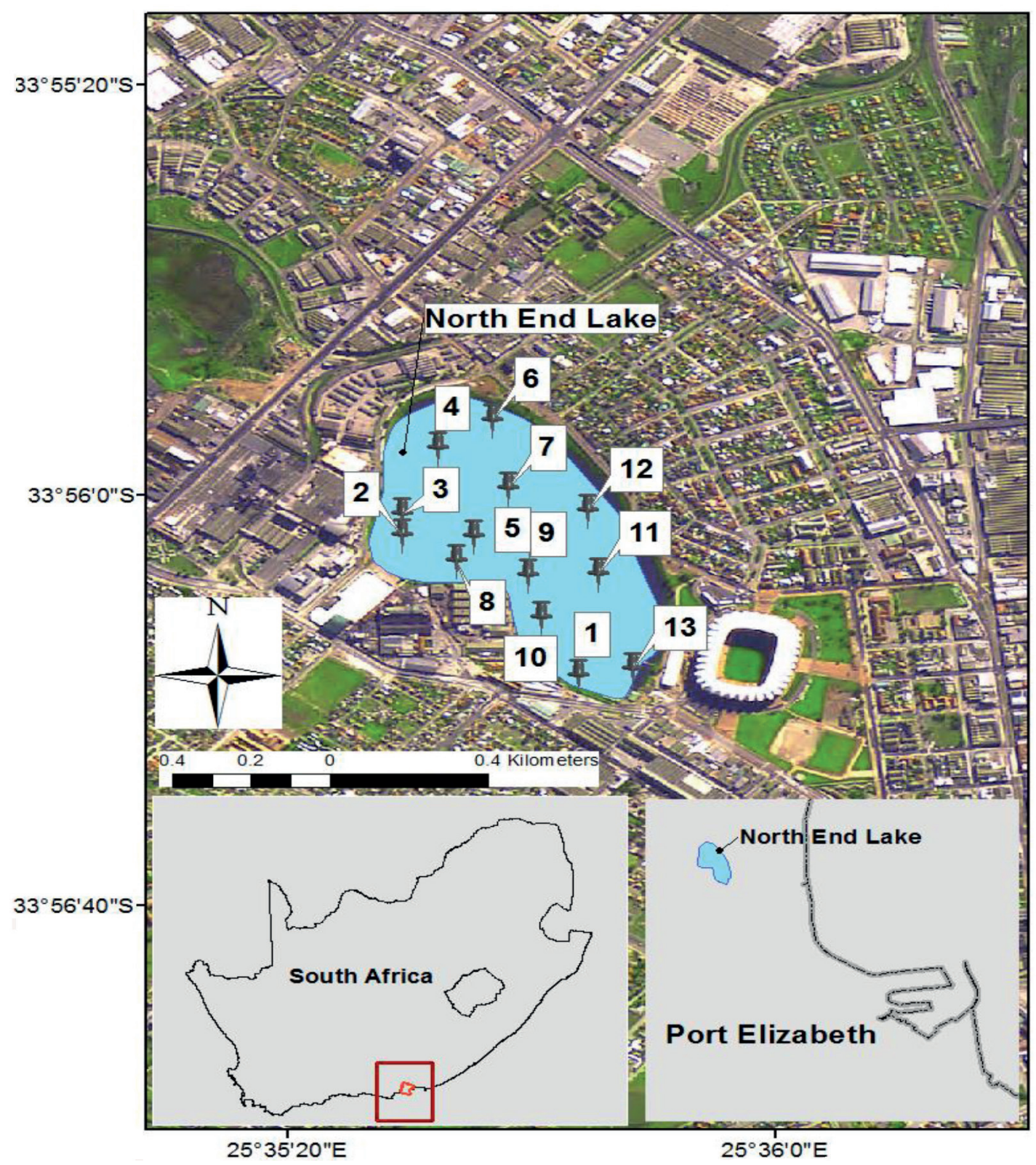

Figure 1

Map of Port Elizabeth, South Africa, showing the sampling sites in North End Lake

coupled to an Agilent 5975 mass spectrometer detector (MSD). The capillary column was a $30 \mathrm{~m} \mathrm{DB}-1 \mathrm{~ms}(100 \%$ dimethylsiloxane, CJ \& W Scientific, CA, USA) with an internal diameter of $0.25 \mathrm{~mm}$, length of $30 \mathrm{~m}$ and a stationary phase thickness of $0.25 \mathrm{~m}$. The oven temperature was set at $100^{\circ} \mathrm{C}$ (initial hold of $1 \mathrm{~min}$ ), raised to $325^{\circ} \mathrm{C}$ at a rate of $15^{\circ} \mathrm{C} / \mathrm{min}$ and held for $5 \mathrm{~min}$. The injector, transfer line and quadrupole temperatures were 250,280 and $150^{\circ} \mathrm{C}$, respectively. The carrier gas was helium at a constant flow rate of $1.2 \mathrm{~mL} / \mathrm{min}$. The injection volume was $1 \mu \mathrm{L}$ in the splitless mode. The MS was operated at $70 \mathrm{eV}$ under selected ion monitoring (SIM) in the electron ionization (EI) mode. The molecular mass and two additional confirming ions corresponding to the molecular ion cluster of each analyte $[\mathrm{M}]^{+}$and $\left[\mathrm{M}-\mathrm{Cl}_{2}\right]^{+}$for loss of two chlorines established the presence of the analyte.

\section{Quality assurance}

Certified pure standards (IUPAC nos. 28, 52, 101, 138, 153 and 180) from Sigma Aldrich (South Africa) were used for the quantification of PCBs. The target analytes were identified in the sample extracts by comparing the retention times from the standard mixture and quantified using the response factors from the calibration curves of the standards. A procedural blank and matrix blank were processed through the entire procedure and analysed prior to and after every batch of 5 samples. No PCBs were detected in the procedural blanks. The mean recovery of PCBs from 3 replicate sediment samples varied between $78.42 \pm 4.42$ to $98.28 \pm 2.65 \%$ and the surrogate recoveries were found to be $98.62 \pm 5.38$.

Limits of detection (LOD) and limit of quantification were calculated as the analyte concentration yielding a signal 3 
times or 10 times the standard deviation of the PCB level in the blanks and ranged between 0.01 and $0.20 \mathrm{ng}^{-1} \mathrm{~g}^{-1}$ and 0.04 and $0.66 \mathrm{ng} \cdot \mathrm{g}^{-1}$, respectively. The ratio between two monitored ions was within satisfactory level $( \pm 0.2)$ of the ratio found for the relevant congener in the standard. The linearity of the method was evaluated using calibration curves with the target analytes and the correlation coefficient of $r^{2}>0.995$. The relative standard deviation was $\leq 20 \%$.

\section{Data analysis}

The data were analysed with Statistica software (Version 11.0). Statistically significant differences were determined using oneway analysis of variance (ANOVA) and the $t$-test. All tests were considered statistically significant at $p$-value $<0.05$. However, statistical significance does not necessarily imply that the result is important in practice and therefore effect sizes were calculated to determine their practical significance. For the comparison of the means of two groups, Scheffè's test was used to calculate the effect size using the following formula (Ellis and Steyn, 2003):

$$
d=\left|\overline{X_{1}}-\overline{X_{2}}\right| / S_{\max }
$$

where: $d=$ Cohen's $d$ effect size and $\bar{X}_{1}$ and $\bar{X}_{2}=$ averages of the two groups compared and $S_{\max }$ is the largest standard deviation of the two groups. If $d<0.5$, the effect size is small; $d$ : $0.5-0.79$, the effect size is medium and an effect size is large when $d>0.8$. Data with $d>0.8$ is considered practically significant, since it is the result of a difference having a large effect (Ellis and Steyn, 2003).

\section{RESULTS}

\section{Particle size distribution and sediment organic matter content}

The sediment characteristics (particle size and organic matter) are known to influence PCB distribution in environmental matrices due to the sorption process. Sediment particles were composed of sand, silt and clay (Table 1). The total organic matter content in the sediment samples varied between 5.76 and $18.85 \%$, with an average of $12 \%$ overall. High organic matter content of over $10 \%$ was found at the majority of the sites. High organic matter content was found at the Sites 8 and 6 (18.85 and 18.37\%), respectively. The textural class of sediments collected at these sites was silt loam. A significant difference was observed among the grain-sizes $(F=16.07, p<0.05)$. Low organic matter contents were found at Sites 1 and 13. The grain fractions at these sites were mostly sandy. Sediment grain-size distributions varied among the sampling sites.

\begin{tabular}{|l|c|c|c|c|c|}
\hline \multicolumn{7}{|c|}{ Organic matter content (\%) and particle sizes (\%) of the sediment samples } \\
\cline { 2 - 5 } \multirow{2}{*}{ Sites } & $\begin{array}{c}\text { Organic } \\
\text { matter (\%) }\end{array}$ & Sand & Clay & Silt & \multirow{2}{*}{ Textural class } \\
\hline 1 & 5.76 & 58.63 & 27.77 & 13.58 & Sandy clay loam \\
\hline 2 & 16.63 & 21.73 & 10.12 & 68.11 & Silt clay loam \\
\hline 3 & 9.53 & 39.16 & 15.98 & 44.86 & Loam \\
\hline 4 & 16.14 & 39.16 & 8.16 & 52.66 & Silt loam \\
\hline 5 & 8.74 & 45.03 & 21.72 & 33.23 & Soam \\
\hline 6 & 18.37 & 25.59 & 17.89 & 56.51 & Silt loam \\
\hline 7 & 11.75 & 43.08 & 27.77 & 29.14 & Silt loam loam \\
\hline 8 & 18.85 & 29.45 & 17.77 & 52.76 & Sandy loam \\
\hline 9 & 13.93 & 72.18 & 17.89 & 9.93 & Soamy fine sand \\
\hline 10 & 9.24 & 85.65 & 12.05 & 2.28 & Sandy clay loam \\
\hline 11 & 13.73 & 56.64 & 25.84 & 17.51 & Sandy loam \\
\hline 12 & 10.21 & 56.65 & 17.89 & 25.46 & Sandy loam \\
\hline 13 & 3.54 & 58.64 & 19.81 & 21.56 & \\
\hline
\end{tabular}

\begin{tabular}{|l|c|c|c|c|c|c|c|}
\hline \multicolumn{7}{|c|}{ PABLE 2 } \\
\hline PCB concentrations (ng.g-1 & Tw) in sediment samples (mean \pm standard deviation, $\boldsymbol{n}=\mathbf{3}$ ) \\
\hline 1 & PCB 28 & PCB 52 & PCB 101 & PCB 138 & PCB 153 & PCB 180 & Total PCBs \\
\hline 2 & $0.06 \pm 0.19$ & $0.18 \pm 0.39$ & $0.26 \pm 0.18$ & $0.74 \pm 0.22$ & $0.44 \pm 0.34$ & $0.20 \pm 0.26$ & $1.88 \pm 0.24$ \\
\hline 3 & $0.22 \pm 0.16$ & $0.18 \pm 0.14$ & $0.38 \pm 0.18$ & $0.91 \pm 0.34$ & $0.61 \pm 0.19$ & $0.34 \pm 0.08$ & $2.64 \pm 0.27$ \\
\hline 4 & nd & $0.09 \pm 0.24$ & $0.32 \pm 0.27$ & $0.88 \pm 0.23$ & $0.58 \pm 0.38$ & $0.15 \pm 0.03$ & $2.03 \pm 0.34$ \\
\hline 5 & $0.26 \pm 0.18$ & $0.23 \pm 0.13$ & $0.22 \pm 0.14$ & $0.80 \pm 0.25$ & $0.72 \pm 0.43$ & $0.21 \pm 0.02$ & $2.44 \pm 0.24$ \\
\hline 6 & nd & $0.14 \pm 0.06$ & $0.33 \pm 0.25$ & $0.78 \pm 0.34$ & $0.54 \pm 0.32$ & $0.14 \pm 0.07$ & $1.93 \pm 0.29$ \\
\hline 7 & $0.13 \pm 0.16$ & $0.20 \pm 0.26$ & $0.26 \pm 0.14$ & $1.01 \pm 0.26$ & $1.26 \pm 0.19$ & $0.20 \pm 0.04$ & $3.06 \pm 0.31$ \\
\hline 8 & $0.43 \pm 0.32$ & $0.27 \pm 0.42$ & $0.31 \pm 0.07$ & $0.47 \pm 0.13$ & $0.57 \pm 0.21$ & $0.18 \pm 0.05$ & $2.22 \pm 0.26$ \\
\hline 9 & $0.13 \pm 0.18$ & $0.13 \pm 0.03$ & $0.32 \pm 0.03$ & $0.96 \pm 0.13$ & $0.57 \pm 0.08$ & $0.29 \pm 0.01$ & $2.39 \pm 0.32$ \\
\hline 10 & $0.35 \pm 0.23$ & $0.30 \pm 0.34$ & $0.17 \pm 0.08$ & $0.44 \pm 0.09$ & $0.70 \pm 0.06$ & $0.24 \pm 0.29$ & $2.20 \pm 0.25$ \\
\hline 11 & $0.34 \pm 0.12$ & $0.21 \pm 0.32$ & $0.30 \pm 0.07$ & $0.60 \pm 0.20$ & $0.94 \pm 0.11$ & $0.24 \pm 0.02$ & $2.63 \pm 0.23$ \\
\hline 12 & nd & nd & $0.30 \pm 0.04$ & $0.94 \pm 0.15$ & $0.70 \pm 0.18$ & $0.30 \pm 0.02$ & $2.25 \pm 0.38$ \\
\hline 13 & nd & $0.04 \pm 0.09$ & $0.25 \pm 0.10$ & $0.83 \pm 0.24$ & $0.50 \pm 0.16$ & $0.13 \pm 0.04$ & $1.75 \pm 0.31$ \\
\hline
\end{tabular}

nd: not detected 


\section{PCB levels in sediments}

The concentrations of PCB congeners in sediments from North End Lake are presented in Table 2. All PCB congeners were observed in most of the investigated sediment samples. The PCB concentrations in surface sediments ranged from 1.60 to $3.06 \mathrm{ng} \cdot \mathrm{g}^{-1} \mathrm{dry}$ weight $(\mathrm{dw})$. The concentrations of measured PCBs were not highly variable at the different stations. The highest concentration (3.06 ng. $\left.\mathrm{g}^{-1}\right)$ was observed in sediments collected from Site 6 with predominance of PCB $153\left(1.26 \mathrm{ng} \cdot \mathrm{g}^{-1} \mathrm{dw}\right)$ and PCB 138 (1.01 ng. $\mathrm{g}^{-1} \mathrm{dw}$ ) (Table 2). On the other hand, the lower PCB concentration was detected at Site 13.

Among the studied PCB congeners, PCB 138 was the most abundant in the investigated samples with an average concentration of $0.78 \pm 0.16 \mathrm{ng} \cdot \mathrm{g}^{-1}$, followed by PCB 153

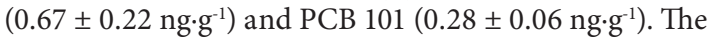
hexachlorinated biphenyl congeners (PCBs 138 and 153) contributed more than $60 \%$ to the total PCBs in the sediments analysed. PCB 138 showed predominance at Sites 3,11 and 12 (> 40\%) while PCB 153 was dominant at Sites 6, 10 and $13(41 \%$ at each of these three sites) (Fig. 2).

\section{DISCUSSION}

The concentrations of 6 indicator PCB congeners were tested in sediment samples from North End Lake. A significant difference was observed between the six indicator congeners $(F=43.5, p<0.05)$. Similarly, a significant difference was observed between mean concentrations of the indicator PCB congeners $(p<0.05 ; d>0.8)$. Mean concentration of PCB 138 was significantly higher than mean concentrations of PCBs $28,52,101$ and $180(p<0.05)(d=3.38,4.42,3.99$ and 4.51$)$, respectively. Similarly, PCB 153 was significantly higher in concentration than PCBs 28, 52, 101 and $180(p<0.05)$ $(d=2.42,2.95,2.40$ and 2.81), respectively. However, no statistically significant difference was observed between concentrations of congener nos. 28, 52, 101 and $180(p>0.05)$ as well as between PCB 138 and PCB 153 ( $p>0.05)$. The distribution of PCBs in sediments was: $\mathrm{PCB} 138>\mathrm{PCB}$ $153>$ PCB $101>$ PCB $180>$ PCB $28>$ PCB 52 (Fig. 2).

PCBs are known to sorb to organic matter and sediment grains and this can be used to explain the distribution of PCBs in sediments. The analysis showed that a positive correlation exists between sediment organic matter and total PCB concentrations in sediment samples (Fig. 3) $(p<0.05)$. There was no correlation of contaminant content to particle fraction (sand and clay). However, there was a significant correlation with silt fraction $(r=0.35, p<0.05)$.

The six PCB congeners detected in the present study are considered environmentally persistent and predominantly present in most PCB mixtures and in environmental samples such as soils and sediments (Zhao et al., 2006). North End Lake receives domestic sewage and industrial waste, which may be contaminated by a variety of chemicals. The distribution of PCBs indicates that areas of the lake affected by stormwater and inflow discharge are subjected to more PCB contamination than other sampling locations (Sites 2, 4 and 6). The highest total PCB level was detected at Site 6 (3.06 ng.g $\left.{ }^{-1}\right)$; persistence of PCBs in this area may be linked to the high content of sediment organic matter and the particle size (silt) (Table 1) and due to the location of this site which is near the inflow water pipes from the surrounding areas, therefore a possible localized pollutant discharge source is suspected. The lowest concentration was detected at Site $13\left(1.60 \mathrm{ng} \cdot \mathrm{g}^{-1} \mathrm{dw}\right)$ which is in

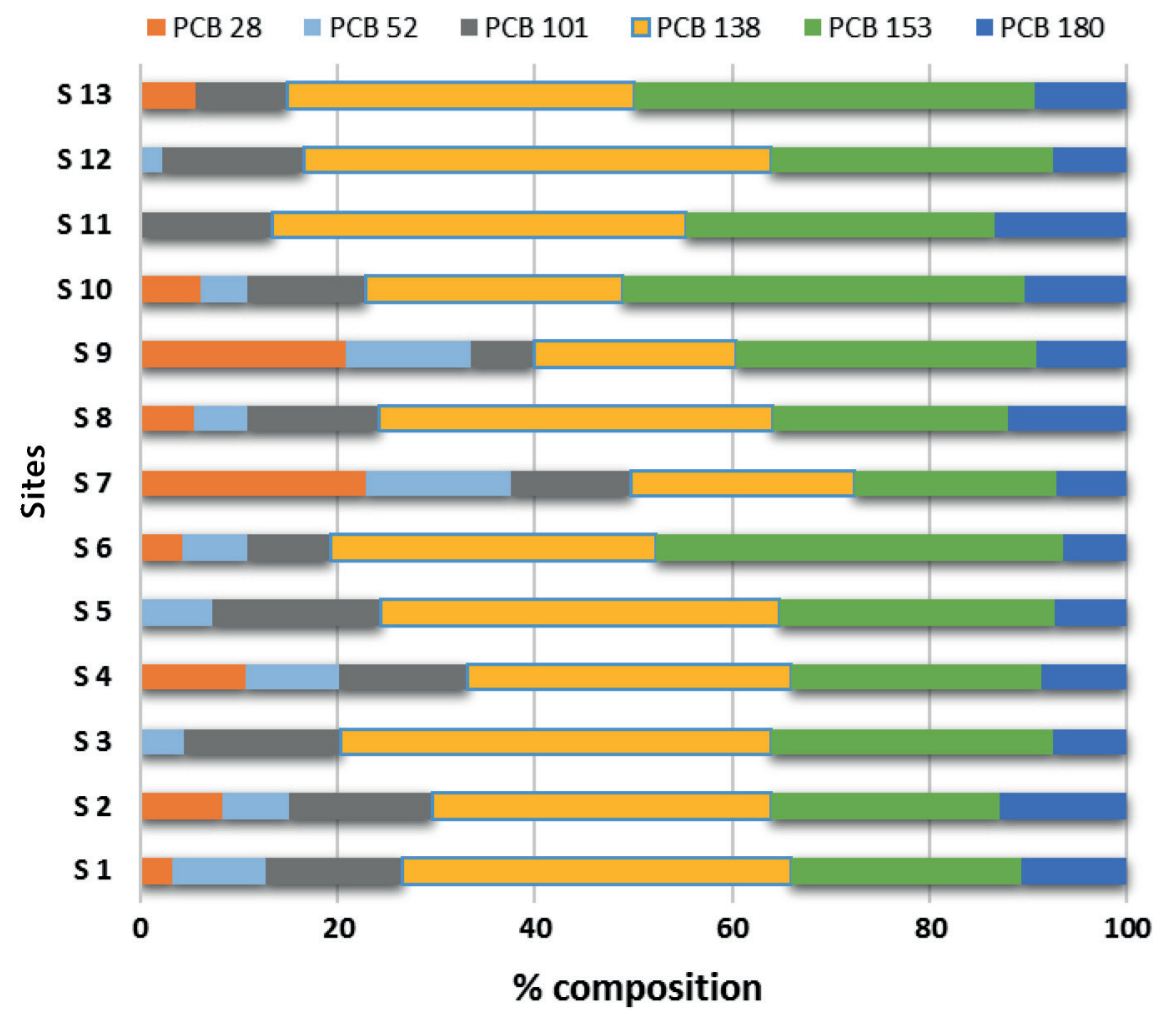

Figure 2

Composition (\%) of indicator PCB congeners in sediment samples 


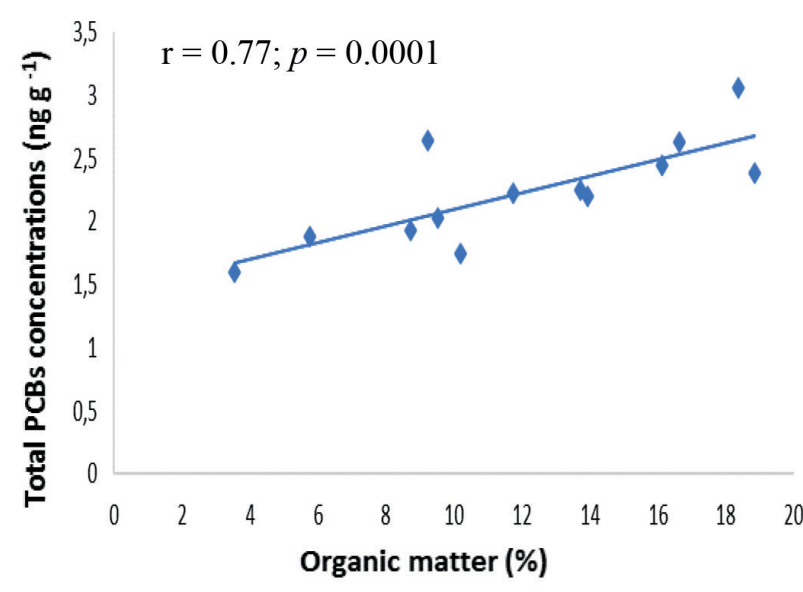

Figure 3

Total PCB levels versus organic matter content of sediments

the proximity of Nelson Mandela Bay Stadium, i.e., no runoff or stormwater drains were observed around this site. However, the differences in concentrations of PCBs in sediments are not only due to anthropogenic impacts, but also to the organic content and grain size of the sediment. It is well-known that sediments having a high organic matter content but also a high proportion of the fine grain size fraction $(<2 \mu \mathrm{m})$ accumulate far higher amounts of pollutants than sandy sediments (Baeyens et al., 1991). The findings from this study revealed that high concentrations of PCB congeners were related to organic matter, silt and fine sand. The observed positive correlation of contaminant concentrations with organic matter confirms a well-known strong affinity to organic matter for organic chemicals such as PCBs due to the strength of their hydrophobic characters (Prokeš et al., 2014). In addition, some studies indicated that PCB levels in sediments are subject to the affinity between organic matter and grain size. Delbeke et al. (1990) showed that PCB levels in the sediment reveal a higher affinity for the sediment size fraction $<63 \mu \mathrm{m}$. A study by Evans et al. (1990) suggested that the organic matter content of sediment increases with decreasing particle size. Doyle et al. (2003) indicated that anthropogenic organic compounds tend to sorb and concentrate in finer grained sediments such as fine silt and fine sand. These findings confirmed that grain size of sediments is an important factor governing the accumulation of PCB contaminants in sediments. In the present study, the fractions of sediment samples at Sites 1 and 13 were moderately fine (sandy loam), with a lower content of organic matter (5.76 and 3.54\%), respectively. The results showed that the high sand proportion implies that the capacity of sediments to adsorb organic pollutants (PCBs) is low. However, Davies et al. (2010) found that a high sand fraction favours abiotic processes and increases diffusion of oxygen into the sediment, making pollutants more bioavailable due to faster oxidation of organic matter and simultaneous release of associated persistent organic micro-pollutants such as PCBs.

The industrialization of Port Elizabeth may account for PCBs in the sediments of North End Lake, where numerous industries are situated. PCBs found major use in industries as a dielectric in the electrical power distribution industry, especially in infrastructures (NIP, 2011). A power station, using water from the North End Lake for cooling, had begun to generate considerably more electricity at the beginning of the Second World War to satisfy the increased demand at the time (García-Rodríguez et al., 2007). Considering that the cooling water was returned to the lake, it may have received wastes or PCB leakage from that power station, which operated until 1974.

The indicator PCBs $28,52,101,138,153$, and 180 , are major congeners detected in environmental samples (Hsieh et al., 2011; Ahmadkhaniha et al., 2017). The prevalence of high levels of PCBs 138 and 153 detected in the present study is in keeping with other findings reflecting the high persistence among the indicator PCB congeners commonly present in various sample matrices (Carro et al., 2000; EFSA, 2010). The higher congeners were generally more prevalent and it is well known that the biodegradability of PCBs decreases as the number of chlorine atoms increases (Correa et al., 2010; Quinn et al., 2013; Zhang et al., 2015). Further, the highly chlorinated PCB congeners are more likely to be adsorbed to particulate material resulting in accumulation and deposition in the sediment. They have relatively low mobility and hence tend to remain closer to the contamination source, whereas lighter PCB congeners may be subject to microbial degradation and volatilisation (Piñeiro et al., 1996; Anyasi and Atagana (2011). The hydrophobicity which increases with molecular weight seems to be responsible for the stronger sorption on the organic matter of the sediment size fractions.

No data on PCB contamination in North End Lake are available to compare the trends of concentrations in sediment samples. In South Africa, the literature indicates little research on PCB content in sediments. Greichus et al. (1977) reported on PCBs measured in sediments of water bodies from South Africa in the Voëlvlei Dam, Western Cape: $\left(0.06 \mathrm{ng} \cdot \mathrm{g}^{-1}\right)$ and the Hartbeespoort dam, North-West Province $\left(0.32 \mathrm{ng} \cdot \mathrm{g}^{-1} \mathrm{dw}\right)$. Grobler (1994) also checked for the presence of PCBs (Aroclor 1254 and 1260) in the sediment of the Olifants River in Mpumalanga, but the levels were below the detection limit. The levels reported by Greichus et al. (1977) were two-fold greater in magnitude compared to the levels detected in the present study. Compared to the concentrations reported from other developing and industrially developed countries around the world, PCB concentrations measured in the present study were similar to those reported by Guzzella et al. (2005), Rajendran et al. (2005), He et al. (2006), El-Khady et al. (2007), and Verhaert et al. (2013) (Table 3). All of these studies were conducted in developing countries, namely, India, China, Egypt and Democratic Republic of Congo, respectively. However, the levels of total PCBs in this study were higher than the total PCBs of similar congeners reported by Ssebugere et al. (2014) in sediments from the Napoleon Gulf in Uganda, but lower than the ones from Lakes Maryut, Manzala, and Qarum in Egypt

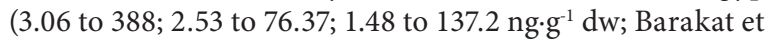
al., 2012a, 2012b, 2013) and rivers in Tianjin in China (44 to $154 \mathrm{ng} \cdot \mathrm{g}^{-1} \mathrm{dw}$; Liu et al., 2003, 2007, 2008). The levels of total PCBs reported in sediments from developed countries (France, Spain, USA, Poland and Canada) were generally higher than the PCB residues reported in the studied area, suggesting greater industrial activities, and various waste discharges in the environment. Mochungong and Zhu (2015) indicated that the history of PCBs is longer and more extensive in developed countries than in developing nations, and the contamination is also relatively more serious in developed countries. A study by Sapozhnikova et al. (2004) reported sediment concentrations varying from 116 to $304 \mathrm{ng} \cdot \mathrm{g}^{-1} \mathrm{dw}$ in Salton Sea (USA), despite PCB production ending in the late 1970s in America. Syakti et al. (2012) analysed 7 indicator PCBs in marine sediments 
TABLE 3

PCB concentrations in the North End Lake sediments and other areas worldwide

\begin{tabular}{|c|c|c|c|}
\hline Location & Country & PCB extent $\left(\mathbf{n g} \cdot \mathbf{g}^{-1} d w\right)$ & References \\
\hline North End Lake & South Africa & $1.60-3.06$ & Present study \\
\hline Napoleon Gulf, Lake Victoria & Uganda & $0.362-0.848$ & Ssebugere et al. (2014) \\
\hline North-east India & India & $0.18-2.33$ & Guzzella et al. (2005) \\
\hline Bay of Bengal & India & $0.02-6.57$ & Rajendran et al. (2005) \\
\hline Nile River & Egypt & $1.5-2.2$ & El-Khady et al. (2007) \\
\hline Congo River Basin & Democratic Republic of Congo & $<0.05-1.4$ & Verhaert et al. (2013) \\
\hline Yellow River & China & $1.4-5.3$ & He et al. (2006) \\
\hline Salton Sea & USA & $116-304$ & Sapozhnikova et al. (2004) \\
\hline Mediterranean basin & France & $11.5-751.5$ & Syakti et al. (2012) \\
\hline Thau Lagoon & France & $0-28.3$ & Leaute (2008) \\
\hline Sea lots & Spain & $62-601$ & Mohammed et al. (2011) \\
\hline Ontario Lake & Canada & $2.6-255$ & Marvin et al. (2004) \\
\hline Odra River & Poland & $2.7-412$ & Kannan et al. (2003) \\
\hline \begin{tabular}{|l|} 
Rivers in Tianjin \\
\end{tabular} & China & $44-154$ & Liu et al. (2007) \\
\hline Yangtze Estuary & China & $0.19-18.95$ & Liu et al. $(2003,2008)$ \\
\hline Lake Maryut & Egypt & $3.06-388$ & Barakat et al. (2012a) \\
\hline Lake Manzala & Egypt & $2.53-76.37$ & Barakat et al. (2012b) \\
\hline Lake Qarum & Egypt & $1.48-137.2$ & Barakat et al. (2013) \\
\hline
\end{tabular}

directly exposed to wastewater from Cortiou, Marseille, in France and found levels of PCBs ranging from 11.5 to $791.5 \mathrm{ng} \cdot \mathrm{g}^{-1} \mathrm{dw}$ while Marvin et al. (2004) reported PCB levels ranging from 2.6 to $255 \mathrm{ng} \cdot \mathrm{g}^{-1} \mathrm{dw}$ in sediments from Ontario Lake in Canada. Kannan et al. (2003) revealed PCB levels ranging from 2.7 to $412 \mathrm{ng} \cdot \mathrm{g}^{-1} \mathrm{dw}$ in sediments from Odra River and its tributaries in Poland.

Sediments are heterogeneous in composition and the different components exhibit different interactions with the contaminants. To evaluate and compare PCB contaminants in sediments from North End Lake, PCB levels detected in the present study were compared to the Interim freshwater Sediment Quality Guidelines (ISQGs) of $34.1 \mathrm{ng} \cdot \mathrm{g}^{-1}$ (CCME, 2001) and the South African recommended sediment

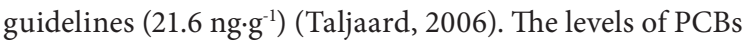
detected in the present study were lower compared to the limits of the above-mentioned.

\section{CONCLUSION}

The present study was the first of its kind focusing on the levels of PCB pollutants in the sediments of the North End Lake in South Africa. The levels of PCB congeners in the North End Lake sediment decreased in the order: $\mathrm{PCB} 138>\mathrm{PCB}$ $153>$ PCB $101>$ PCB $180>$ PCB $28>$ PCB 52. PCB 138 was found to be the most abundant congener present in the lake sediments. The PCB residues detected in this study were likely the results of accidental, unintentional waste disposal and possible illegal dumping into the lake. It frequently happens that wastewater input by stormwater outlets contributes to high contamination because it is estimated that $97 \%$ of released PCBs in a water column are retained in sediment (Urbaniak et al., 2008). Contamination by PCBs was moderate in relation to similar areas worldwide and lower than the Canadian and South African sediment quality guidelines. Measurable levels of these compounds in the sediments indicate an environment impacted by anthropogenic activities that could negatively affect the aquatic biota of the North End Lake over time. Consequently, human health may be affected through consumption of fish through fishing practices at the lake. Source control measures could be considered for reducing point-source inflow of PCBs, and protecting or restoring sediment quality, particularly in areas that support a diversity of anthropogenic activities (e.g. fishing and tourism).

\section{ACKNOWLEDGEMENTS}

The authors gratefully acknowledge the Nelson Mandela Metropolitan University and the Government of Rwanda through Rwanda Education Board for funding this study.

\section{REFERENCES}

AHMADKHANIHA R, NODEHI RN, RASTKARI N and AGHAMIRLOO HM (2017) Polychlorinated biphenyls (PCBs) residues in commercial pasteurized cows' milk in Tehran, Iran. J. Environ. Health Sci. Eng. 15 15. https://doi.org/10.1186/ s40201-017-0278-y

ALKHATIB EA and WEIGAND C (2002) Parameters affecting partitioning of 6 PCB congeners in natural sediments. Environ. Monit. Assess. 78 1-17. https://doi.org/10.1023/A:1016180422675

ANYASI RO and ATAGANA HL (2011) Biological remediation of polychlorinated biphenyls (PCB) in the environment by microorganisms and plants. Afr. Biotechnol. 10 (82) 18916-18938. https://doi.org/10.5897/AJB10.557

BAEYENS W, PANUTRAKUL S, ELSKENS M, LEERMAKERS M, NAVEZ J and MONTENY F (1991) Geochemical processes in muddy and sandy tidal flat sediments. Geo-Marine Lett. 11 (3-4) 188-193. 188. https://doi.org/10.1007/BF02431011

BARAKAT AO, KHAIRY M and AUKAILY I (2013) Persistent organochlorine pesticide and PCB residues in surface sediments of Lake Qarun, a protected area of Egypt. Chemosphere 90 (9) 
2467-2476. https://doi.org/10.1016/j.chemosphere.2012.11.012

BARAKAT AO, MOSTAFA A, WADE TL, SWEET ST and EL SAYED N B (2012a) Spatial distribution and temporal trends of persistent organochlorine pollutants in sediments from Lake Maryut, Alexandria, Egypt. Mar. Pollut. Bull. 64 (2) 395-404. https://doi. org/10.1016/j.marpolbul.2011.12.019

BARAKAT AO, MOSTAFA A, WADE TL, SWEET ST and EL SAYED N B (2012b) Assessment of persistent organochlorine pollutants in sediments from Lake Manzala, Egypt. Mar. Pollut. Bull. 64 (8) 1713-1720. https://doi.org/10.1016/j.marpolbul.2012.03.022

BENTUM JK, DODOO DK and KWAKYE PK (2012) Accumulation of metals and polychlorinated biphenyls (PCBs) in soils around electric transformers in the Central Region of Ghana. Adv. Appl. Sci. Res. 3 (2) 634-643.

BI X, CHU S, MEN Q and XU X (2002) Movement and retention of polychlorinated biphenyls in a paddy field of WenTai area in China. Agric. Ecosyst. Environ. 89 (3) 241-252. https://doi.org/10.1016/ S0167-8809(01)00210-9

BRIGGS D (1977) Sediments: Sources and Methods in Geography. Butterworth and Co. (Publ.) Ltd., London. 190 pp.

CCME (Canadian Council of Ministers of the Environment) (2001) Canadian sediment quality guidelines for the protection of aquatic life: Introduction. Updated: In Canadian Environmental Quality Guidelines, 1999. Canadian Council of Ministers of the Environment, Winniperg.

CARRO N, SAAVEDRA Y, GARCÍA I, IGNACIO M and MANEIRO J (2000) Distribution patterns of polychlorinated biphenyl congeners in marine sediments and wild mussels from Galicia coast (northwestern Spain). J. Shellfish Res. 20 (3) 1215-1221.

CASTELLS P, PARERA J, SANTOS FJ and GALCERAN MT (2008) Occurrence of polychlorinated naphthalenes, polychlorinated biphenyls and short-chain chlorinated paraffins in marine sediments from Barcelona (Spain). Chemosphere 70 (9) 1552-1562. https://doi.org/10.1016/j.chemosphere.2007.08.034

CLARK KE, GOBAS FAPC and MACKAY D (1990) Model of organic chemical uptake and clearance by fish from food and water. Environ. Sci. Technol. 24 (8) 1203-1213. https://doi.org/10.1021/ es00078a008

CORREA PA, LIN L, JUST CL, HU D, HORNBUCKLE KC, SCHNOOR JL and VAN AKEN B (2010) The Effects of Individual PCB Congeners on the Soil Bacterial Community Structure and the Abundance of Biphenyl Dioxygenase Genes. Environ. Int. 36 (8) 901-906. https://doi.org/10.1016/j.envint.2009.07.015

DAVIES OA and TAWARI CC (2010) Season and tide effects on sediment characteristics of trans-okpoka creek, upper bonny Estuary, Nigeria. Agri. Biol. J. N. Am. 1 (2) 89-96.

DELBEKE K, JOIRIS CR and BOSSICART M (1990) Organochlorines in different fractions of sediments and in different planktonic compartments of the Belgian Continental Shelf and the Scheldt Estuary. Env. Pollut. 66 (4) 325-349. https://doi. org/10.1016/0269-7491(90)90149-7

DIPINTO LM, COULL BC and CHANDLER GT (1993) Lethal and sublethal effects of a sediment-associated PCB Aroclor 1254 on a meiobenthic copepod. Environ. Toxicol. Chem. 12 (10) 1909-1918. https://doi.org/10.1002/etc.5620121017

DOYLE J, SOLBERG T, TIEFENTHALER J, O'BRIEN G, BEHNKE HF, POULSON HD, ELA JP and WILLETT SD (2003) Consensusbased sediment quality guidelines; recommendations for use and application interim guidance. Wisconsin Department of Natural Resources, Wisconsin.

EFSA (European Food Safety Authority) (2010) Results of the monitoring of non-dioxin-like PCBs in food and feed. Scientific report of EFSA. EFSA J. 8 (7) 1701 [35 pp.]. https://doi.org/10.2903/j. efsa.2010.1701

EL-KADY AA, ABDEL-WAHHAB MA, HENKELMANN B, BELAL MH, MORSI MKS, GALAL SM and SCHRAMM KW (2007) Polychlorinated biphenyl, polychlorinated dibenzo-p-dioxin and polychlorinated dibenzofuran residues in sediments and fish of the River Nile in the Cairo region. Chemosphere 68 (9) 1660-1668. https://doi.org/10.1016/j.chemosphere.2007.03.066

ELLIS SM and STEYN HS (2003) Practical significance (effect sizes) versus or in combination with statistical significance (p-values): research note. Manage. Dyn.. 12 (4) 51-53.
EQANI SAMAS, MALIK RN, ZHANG G, MOHAMMAD A and CHAKRABORTY P (2012) Polychlorinated biphenyls (PCBs) in the sediments of the River Chenab, Pakistan. Chem. Ecol. 28 (4) 327-339. https://doi.org/10.1080/02757540.2012.667085

ERICKSON MD and KALEY RG (2011) Applications of polychlorinated biphenyls. Environ. Sci. Pollut. Res. 18 (2) 135-151. https://doi.org/10.1007/s11356-010-0392-1

EVANS KM, GILL RA and ROBOTHAM PWJ (1990) The PAH and organic content of sediment particle size fractions. Water Air Soil Pollut. 51 (1-2) 13-31. https://doi.org/10.1007/BF00211500

GARCÍA-RODRÍGUEZ F, ANDERSON CR and ADAMS JB (2007) Paleolimnological assessment of human impacts on an urban South African lake. J. Paleolimnol. 38 (3) 297-308. https://doi. org/10.1007/s10933-006-9076-8

GE J, WOODWARD LA, LI QX and WANG J (2013) Distribution, sources and risk assessment of polychlorinated biphenyls in soils from the Midway Atoll, North Pacific Ocean. PloS One 8 (8) e71521. https://doi.org/10.1371/journal.pone.0071521

GREICHUS YA, GREICHUS A, AMMAN BD, CALL DJ, HAMMAN DC and POTT RM (1977) Insecticides, polychlorinated biphenyls and metals in African lake ecosystems. I. Hartbeespoort Dam Transvaal and Voëlvlei Dam, Cape Province, Republic of South Africa. Arch. Environ. Contamin. Toxicol. 6 (2-3) 371-83. https:// doi.org/10.1007/BF02097778

GRIMM FA, HU D, KANIA-KORWEL I, LEHMLER HJ, LUDEWIG G, HORNBUCKLE KC, DUFFEL MW, BERGMAN A and ROBERTSON LW (2015) Metabolism and metabolites of polychlorinated biphenyls. Crit. Rev. Toxicol. 45 (3) 245-272. https://doi.org/10.3109/10408444.2014.999365

GROBLER DF (1994) A note on PCBs and chlorinated hydrocarbon pesticide residues in water, fish and sediment from the Olifants River, Eastern Transvaal, South Africa. Water SA 20 187-194.

GUZZELLA L, ROSCIOLI C, VIGANÒ L, SAHA M, SARKAR SK and BHATTACHARYA A (2005) Evaluation of the concentration of $\mathrm{HCH}, \mathrm{DDT}, \mathrm{HCB}, \mathrm{PCB}$ and PAH in the sediments along the lower stretch of Hugli estuary, West Bengal, northeast India. Environ. Int. 31 (4) 523-534. https://doi.org/10.1016/j.envint.2004.10.014

HE MC, SUN Y, LI XR and YANG ZF (2006) Distribution patterns of nitrobenzene and polychlorinated biphenyls in water, suspended particulate matter and sediment from mid- and down-stream of the Yellow River (China). Chemosphere 65 (3) 365-374. https://doi. org/10.1016/j.chemosphere.2006.02.033

HSIEH CY, LEE CL, KUO WC, CHEN TC, YI K, WANG YK and YU BY (2011) PCBs in Donggang River Watershed sediments, Taiwan. J. Environ. Sci. Health A 46 (5) 480-489. https://doi.org/10.1080/10 934529.2011.551727

KANNAN K, KOBER JL, KHIM JS, SZYMCZYK K, FALANDYSZ, J and GIESY JP (2003) Polychlorinated biphenyls, polycyclic aromatic hydrocarbons and alkylphenols in sediments from the Odra River and its tributaries, Poland. Toxicol. Environ. Chem. 85 (4-6) 51-60. https://doi.org/10.1080/0277221042000

KANZARI F, SYAKTI AD, ASIA L, MALLERET L, MILLE G, JAMOUSSI B, ABDERRABBA M and DOUMENQ P (2012) Aliphatic hydrocarbons, polycyclic aromatic hydrocarbons, polychlorinated biphenyls, organochlorine, and organophosphorous pesticides in surface sediments from the Arc River and the Berre lagoon, France. Environ. Sci. Pollut. Res. 19 (2) 559-576. https://doi.org/10.1007/s11356-011-0582-5

KOCAN A, PETRIK J, JURSA S, CHOVANCOVA J and DROBNA B (2001) Environmental contamination with polychlorinated biphenyls in the area of their former manufacture in Slovakia. Chemosphere 43 (4) 595-600. https://doi.org/10.1016/ S0045-6535(00)00411-2

LANA R, VAVROVA M, CASLAVSKY J, SKOUNMALOVA M, BILKOVA A and SUCMAN E (2008) PCBs in samples from the environment of southern Moravia Region, Czech Republic. Bull. Environ. Contamin. Toxicol. 6 574-577. https://doi.org/10.1007/ s00128-007-9189-4

LEAUTE F (2008) Biogéochimie des contaminants organiques HAP, PCB et Pesticides organochlorés dans les sediments de l'étang de Thau (France). Thèse de Doctorat, Université de Pierre et Marie Curie, Paris, France. https://tel.archives-ouvertes.fr/tel-00449516 LIU H, ZHANG Q, WANG Y, CAI Z and JIANG g (2007) Occurrence 
of polychlorinated dibenzo- $p$-dioxins, dibenzofurans and biphenyls pollution in sediments from the Haihe River and Dagu Drainage River in Tianjin City, China. Chemosphere 68 (9) $1772-$ 1778. https://doi.org/10.1016/j.chemosphere.2007.03.061

LIU M, CHENG SB, OU DN, YANG Y, LIU HL, HOU LJ, GAO L and XU SY (2008) Organochlorine pesticides in surface sediments and suspended particulate matters from the Yangtze estuary, China. Environ. Pollut. 156 (1) 168-173. https://doi.org/10.1016/j. envpol.2007.12.015LIU M, YANG Y, HOU L, XU S, OU D, ZHANG $\mathrm{B}$ and LIU Q (2003) Chlorinated organic contaminants in surface sediments from the Yangtze Estuary and nearby coastal areas, China. Mar. Pollut. Bull. 46 (5) 672-676. https://doi.org/10.1016/ S0025-326X(03)00050-X

MANSOUR SA (2009) Persistent organic pollutants (POPs) in Africa: Egyptian scenario. Hum. Exp. Toxicol. 28 (9) 531-566. https://doi. org/10.1177/0960327109347048

MARVIN CH, PAINTER S, CHARLTON MN, FOX ME and THIESSEN PAL (2004) Trends in spatial and temporal levels of persistent organic pollutants in Lake Erie sediments. Chemosphere 54 (1) 33-40. https://doi.org/10.1016/S0045-6535(03)00660-X

MECHLIŃSKA A, WOLSKA L and NAMIEŚNIK J (2010) Isotopelabelled substances in analysis of persistent organic pollutants in environmental samples. Trends Anal. Chem. 29 (8) 820-831. https://doi.org/10.1016/j.trac.2010.04.011

MOHAMMED A, PETERMAN P, ECHOLS K, FELTZ K, TEGERDINE G, MANOO A, MARAJ D, AGARD J and ORAZIO C (2011) Polychlorinated biphenyls (PCBs) and organochlorine pesticides (OCPs) in harbor sediments from Sea Lots, Port-ofSpain, Trinidad and Tobago. Mar. Pollut. Bull. 62 (6) 1324-1332. https://doi.org/10.1016/j.marpolbul.2011.03.043.

MOCHUNGONG P and ZHU J (2015) DDTs, PCBs and PBDEs contamination in Africa, Latin America and south-southeast Asia-a review. IMS Environ. Sci. 2 (2) 374-339. https://doi. org/10.3934/environsci.2015.2.374

NIE X, LAN C, WEI T and YANG Y (2005) Distribution of polychlorinated biphenyls in the water, sediment and fish from the Pearl River estuary, China. Mar. Pollut. Bull. 50 (5) 537-546. https://doi.org/10.1016/j.marpolbul.2004.11.046

NIP (2011) South Africa's Plan for the Implementation of the Stockholm Convention on Persistent Organic Pollutants. URL: http://www.ewasa.org/downloads/files/(Accessed 24 August 2012).

PIÑEIRO MA, YUSTY ML, LOZANO JS and GONZALEZ-BARROS SC (1996) PCB and PCT levels in cultivated and free-living mussels of Galicia (North West Spain). Toxicol. Environ. Chem. 55 (1-4) 31-36. https://doi.org/10.1080/02772249609358321

PROKEŠ R, VRANA B, KOMPRDOVÁ K and KLÁNOVÁ J (2014) Annual dynamics of persistent organic pollutants in various aquatic matrices: a case study in the Morava River in Zlín district, Czech Republic. J. Soils Sediments 14 (10) 1738-1752. https://doi. org/10.1007/s11368-014-0931-3.

QUINN LP, ROOS C, PIETERS R, LØKEN K, POLDER A, SKAARE JU and BOUWMAN H (2013) Levels of PCBs in wild bird eggs: considering toxicity through enzyme induction potential and molecular structure. Chemosphere 90 (3) 1109-1116. https://doi. org/10.1016/j.chemosphere.2012.09.016

RAJENDRAN RB, IMAGAWA T, TAO H and RAMESH R (2005) Distribution of PCBs, HCHs and DDTs, and their ecotoxicological implications in Bay of Bengal, India. Environ. Int. 31 (4) 503-512. https://doi.org/10.1016/j.envint.2004.10.009

SALEM DMA, EL SIKAILY A and EL NEMR A (2014) Organochlorines and their risk in marine shellfish collected from the Mediterranean coast, Egypt. Egypt. J. Aquat. Res. 40 (2) 93-101. https://doi.org/10.1016/j.ejar.2014.03.004

SAPOZHNIKOVA Y, BAWARDI O, and SCHLENK D (2004) Pesticides and PCBs in sediments and fish from the Salton Sea, California, USA. Chemosphere 55 (6) 797-809. https://doi. org/10.1016/j.chemosphere.2003.12.009

SORELL T and McEVOY K (2013) Incorporating bioavailability considerations into the evaluation of contaminated sediment sites. Remed. J. 23 (1) 63-72. https://doi.org/10.1002/rem.21338

SSEBUGERE P, SILLANPÄÄ M, KIREMIRE BT, KASOZI GN, WANG P, SOJINU SO, OTIENO PO, ZHU N, ZHU C, ZHANG H, SHANG H, REN D, LI Y, ZHANG Q, JIANG G (2014) Polychlorinated biphenyls and hexachlorocyclohexanes in sediments and fish species from the Napoleon Gulf of Lake Victoria, Uganda. Sci. Total Environ. 481 55-60. https://doi.org/10.1016/j.scitotenv.2014.02.039

SYAKTI AD, ASIA L, KANZARI F, UMASANGADJI H, MALLERET L, TERNOIS Y, MILLE G and DOUMENQ P (2012) Distribution of organochlorine pesticides (OCs) and polychlorinated biphenyls (PCBs) in marine sediments directly exposed to wastewater from Cortiou, Marseille. Environ. Sci. Pollut. Res. 19 (5) 1524-1535. https://doi.org/10.1007/s11356-011-0640-Z

TALJAARD S (2006) The development of a common set of water and sediment quality guidelines for the coastal zone of the BCLME (Project BEHP/LBMP/03/04) Report submitted to UNOPS as part of the Benguela Current Large Marine Ecosystem Programme. CSIR Report CSIR/NRE/ECO/ER/2006/0011/C. CSIR, Stellenbosch. URL: www. bclme. org.

TASHIRO Y, TAKAHIRA K, OSADA H, FUJII H and TOKUYAMA A (2004) Distribution of polychlorinated biphenyls (PCBs), lead, and cadmium in Manko Tidal Flat, Okinawa. Limnology 5 (3) 177-183. https://doi.org/10.1007/s10201-004-0132-7

URBANIAK M, ZIELINSKI M, WESOLOWSKI W and ZALEWSKI M (2008) PCB and heavy metal contamination in bottom sediments from three reservoirs of different catchment characteristics. Pol. J. Environ. Stud. 17 (6) 941-949.

VERHAERT V, COVACI A, BOUILLON S, ABRANTES K, MUSIBONO D, BERVOETS L, VERHEYEN E and BLUST R (2013) Baseline levels and trophic transfer of persistent organic pollutants in sediments and biota from the Congo River Basin (DR Congo). Environ. Int. 59 290-302. https://doi.org/10.1016/j. envint.2013.05.015

ZHAO G, XU Y, HAN g and LING B (2006) Biotransfer of persistent organic pollutants from a large site in China used for the disassembly of electronic and electrical waste. Environ. Geochem. Health 28 (4) 341-351. https://doi.org/10.1007/s10653-005-9003-3 ZHOU HY and WONG MH (2000) Accumulation of sedimentsorbed PCBs in Tilapia. Water Res. 34 (11) 2905-2914. https://doi. org/10.1016/S0043-1354(00)00049-X

ZHANG H, JIANG X, LU L and XIAO W (2015) Biodegradation of polychlorinated biphenyls (PCBs) by the novel identified cyanobacterium Anabaena PD-1. PLoS ONE 10 (7) e0131450. https://doi.org/10.1371/journal.pone.0131450 